\title{
INDUSTRY TRAINING STRATEGIES IN AUSTRALIA AND NEW ZEALAND
}

\author{
Chris Dunn \\ Industrial Relations Centre, Victoria Management School \\ Victoria University of Wellington
}

\begin{abstract}
Since the 1980s much emphasis has been placed on the need for a dramatic re-orientation towards workplace education and training in both New Zealand and Australia to up-skill employees so they can participate in the global knowledge society and contribute to the development and growth of national economies. There are similarities in the way government and industries in both countries have responded to these concerns. There has been a shift away from traditional apprenticeships to industry based vocational education and training. This has produced rapid growth in the numbers of participants. However there are significant differences in the structure and philosophy of training provision in each country. This raises questions about the comparative efficacy of the processes, and relevance of outcomes to intended goals. Comparing the two 'systems' helps us step back from the fog of policy and quantitative achievement measures to see more clearly issues of concern and perhaps how they may be addressed.
\end{abstract}

\section{Introduction}

This paper compares national industry training' strategies introduced in Australia and New Zealand in the 1990s. These strategies account for approximately $20 \%$ of all participants in vocational education and training (VET) in both countries. Although Australia's population is five times that of New Zealand, there is a striking similarity in both the rate of participation per head of population, and the increase in participation in industry training in both countries. Although producing seemingly similar numerical outcomes, the strategies are significantly different.

Figure 1

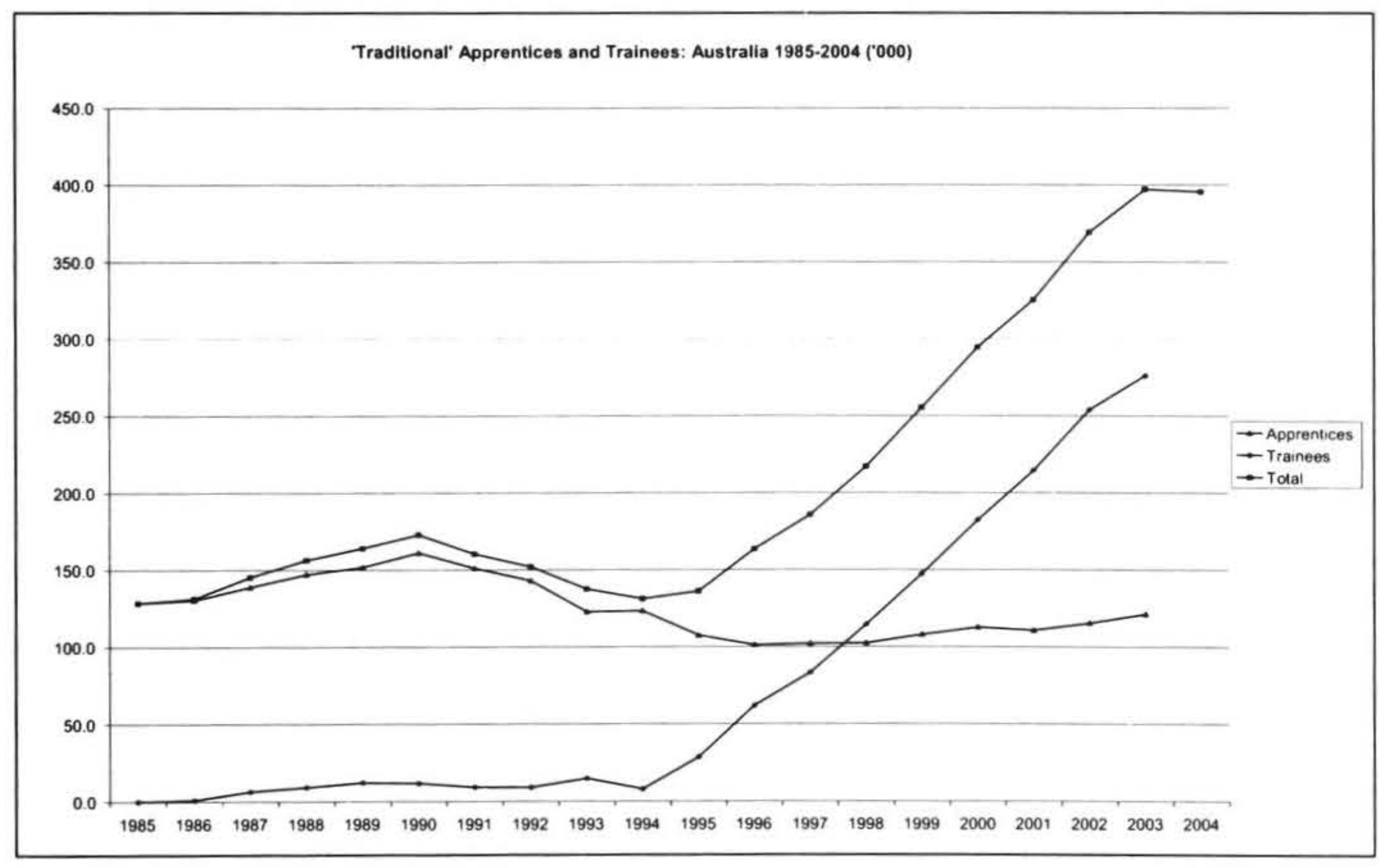

Sources: Brooks, 2004, NCVER, 2004b 


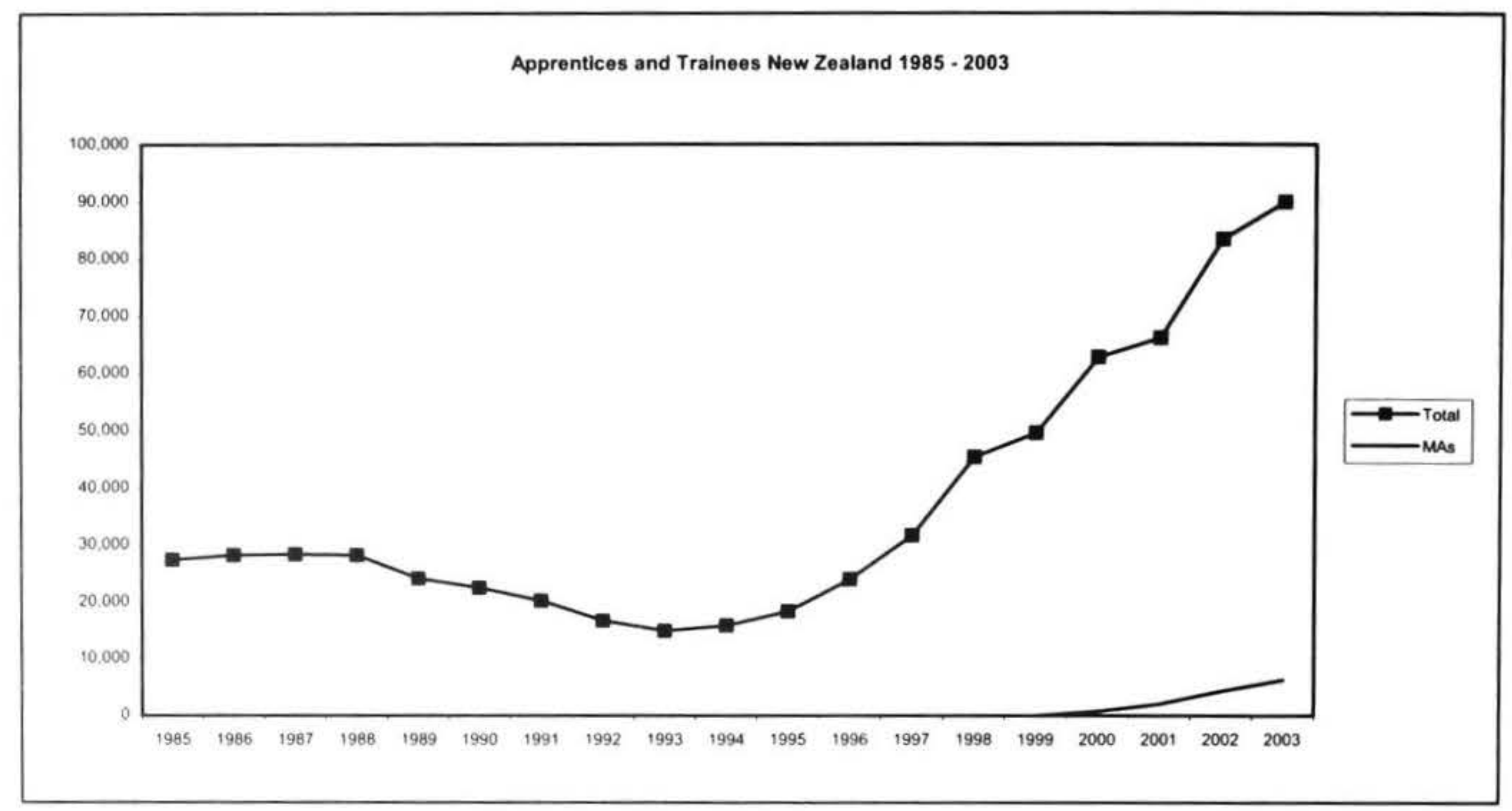

Sources: Green, Hipkins, 2003; TEC, 2004a

In this paper I describe the development and structure of each country's national training strategy and suggest two models to represent these strategies.

The contexts in which both strategies developed in the late 1980s incorporated:

- high levels of unemployment, especially among young people;

- decreasing employment in low skilled jobs especially manufacturing and agriculture, shift to service industry;

- increasing demand for skills with a resulting system of training responsive to skill shortages;

- the decline of traditional apprenticeships;

- increasingly decentralised employment relationships, following 'reform' of industrial relations regulation;

- the desire of employers and industry bodies for control over 'industry based' training;

critique of the public provision of VET as outdated and unresponsive;

- an emphasis on market oriented training provision; and,

- the development of national qualifications systems with competency based assessment and certification that facilitated participation, provision, portability and pathways.

\section{New Zealand's Industry Training Strategy}

In the late $1980 \mathrm{~s}$ several reviews, including the recommendations of the Hawke Report (1989), led to the emergence of an industry training strategy (G. R. Hawke, 1988). These recommendations included:
- the creation of a new Ministry of Education as a policy body;

- the development of a more autonomous, degree oriented polytechnic/VET sector;

- the establishment of the New Zealand Qualifications Authority (NZQA) in 1990 to coordinate qualifications within the New Zealand Qualifications Framework (NQF) and replace existing vocational qualifications with a competency based modular assessment;

- $\quad$ the funding of all tertiary institutions on the basis of student demand through a bulk grant determined by estimation of the number of Equivalent Full-Time Student places (EFTS);

- the increasing involvement of private education and training providers (Private Tertiary Enterprises - PTEs);

- the establishment of the Education and Training Support Agency (ETSA) to take responsibility for apprenticeship and labour market training programmes, to facilitate the Apprenticeship Working Group on apprenticeship reform and negotiate with NZQA to include Apprenticeship within the NQF

The election of a National Party government in late 1990 brought a rapid integration of industry training policy. A new 'Industry Skills' Strategy was announced in the July 1991 budget (ETSA, 1991). Within the deregulatory, decentralising context set by the Employment Contracts Act 1991, there was a concern to establish a structure of qualifications that employers could use in individualised employment negotiations. Employment relationships were shifted towards self-employment, part-time jobs, and casual and limited-duration work. 
A main feature of the Industry Skills Strategy was that industry specific Training Organisations (ITOs) were responsible for the management of training for their industries. The government intended to initially provide establishment funding with a subsequent move to industry funding. A Training Development Fund of \$2.1 million for the 1991/1992 period, was provided to assist ITOs to carry out training needs analysis and develop new training. The NZQA would work with ITOs to develop competency based qualifications and standards (Barrowman, 1996). The participation of disadvantaged groups, including Maori, Pacific people and women was to be addressed.

The Industry Training Act (1992) came into force in April 1992. It contained no clear definition of industry, the possible range of an ITO's coverage or the number of ITOs. Future funding and the role of ITOs in subsidising training were also unspecified. The vague drafting was intended to allow industries to decide these issues themselves.

Early ITOs emerged from the relevant industry associations and training boards, especially in areas where training was well established and resourced. As delays in ITO establishment and standards development hindered the process some critics claimed that existing industry training boards were not up to the demands of the new strategy (Hall, 1995).

At the end of April, 1993, ETSA and the NZQA cooperated to launch Skill New Zealand to consult with the Industry Training Task Force, polytechnics, industries and school principals (ETSA, 1994). A more unified structure of training linked to the NQF was developed through the promotion of Skill New Zealand programmes including Skill Start for industry training, Skill Pathways for VET in schools and labour market programmes.

Initially number of traditional apprentices fell from 22,500 in 1990 to 14,904 in 1993 ; trainee numbers then began to rise slowly as industry trainees were recruited. The government tried to kick-start industry training between 1993 and 1996 by paying employers $\$ 1000$ per trainee. This was the only time a financial incentive for recruitment applied (ETSA, 1995). Trainee numbers increased to 15,805 in $1994,18,344$ in 1995 , and 23,957 in 1996 and continued upwards. By July 1995 there were 47 ITOs (ETSA, 1996); in 2005 there are 41.

The funding of industry training in the first half of the 1990s was uncertain; ITOs were dependent upon the generosity of industry bodies and ETSA funding. Many ITOs had difficulty managing growth and some were at risk of failing. ITOs argued that sustained government funding was essential to their growth and viability. A new Industry Training Fund was introduced in July 1995 (Green et al., 2003). Funding was based upon a Standard Training Measure (STM) where one STM was equal to a "trainee who has completed a training arrangement designed to lead to the achievement of a 120 credit National Certificate" (ETSA, 1996:20). ETSA purchased a contracted number of STMs from an ITO on the basis of ITO forecasting and monitored ITO performance. By 1999 government funding of industry training was calculated annually and capped for the year. This funding structure gave a degree of increased certainty to ITOs. As they became more established further funding was available which led to increasing numbers. The National Government was reluctant to increase funding, although industry contributions did increase as is demonstrated by the following table.

Table 1: Industry and Government Cash Contributions to Industry Training Fund 1996-2004 (\$million)

\begin{tabular}{|l|c|c|c|c|c|c|c|c|c|}
\hline & $\mathbf{1 9 9 6}$ & $\mathbf{1 9 9 7}$ & $\mathbf{1 9 9 8}$ & $\mathbf{1 9 9 9}$ & $\mathbf{2 0 0 0}$ & $\mathbf{2 0 0 1}$ & $\mathbf{2 0 0 2}$ & $\mathbf{2 0 0 3}$ & $\mathbf{2 0 0 4}$ \\
\hline Government & 50.1 & 61.7 & 67.8 & 63.1 & 65.9 & 71.2 & 90.6 & 98.4 & 106.7 \\
\hline Industry & 14.7 & 19.6 & 24.7 & 26.9 & 27.0 & 30.3 & 38.2 & 41.6 & \\
\hline Total & 64.8 & 81.3 & 92.5 & 90.0 & 92.9 & 101.5 & 128.8 & 140.9 & \\
\hline
\end{tabular}

Source: Connell, 2004; Skill New Zealand, 2002; TEC, 2003, 2004

The Government established the Tertiary Education Advisory Commission (TEAC) to review and develop tertiary education policy. The second of four reports, Shaping the System (TEAC, 2001) acknowledged that ITOs should be recognised as tertiary institutions and integrated into the tertiary system. The reports recommended the establishment of a Tertiary Education Commission to oversee the integrated system and a Tertiary Education Strategy to guide its development (Ministry of Education, 2002).

As an indication of the government's commitment to training, a new 'Modern Apprenticeships' programme was introduced in all industry areas to fill the void left by the demise of traditional apprenticeships. Modern
Apprenticeships incorporated the concept of competencybased progression. A coordinator was engaged through an ITO, to mentor and manage the process (Maharey, 2000).

A review of Industry Training included new requirements for ITOs to: identify current and future skill needs; develop strategic training plans to assist industry to meet those needs, and promote the training plans. In keeping with the Labour Government's Employment Relations Act 2000, which encouraged collective bargaining and a greater role for unions, ITOs were required to develop arrangements for collective representation of employees. Procedures were established for ITOs, subject to the agreement of the majority of employers within the 
particular industry, to impose a levy on firms (Ministry of Education, 2001a, 2001b).

The policy framework described in the Tertiary Education Strategy (TES) was released in May 2002 (Ministry of Education, 2002). Changes to industry training and the Tertiary Education Commission (TEC) were ratified in December 2002 in the Education (Tertiary Reform) Amendment Act (2002), and the Industry Training Amendment Act (2002). The TEC became a Crown entity with less autonomy than envisaged by the TEAC reports. The Minister for Education retained power to direct the TEC and the Ministry of Education remained the principal policy adviser (Tertiary Education Reform Bill, 2002).

The Tertiary Education Commission, which came into existence on 1 January 2003, formally incorporated vocational education and training into the tertiary education sector (Skill New Zealand, 2003). The TEC is responsible for 'steering' the system and is governed by a board of institutional representatives that reports to the Minister of Education. It has a number of key functions (Ministry of Education, 2003:21):

- $\quad$ putting government policy into effect;

- negotiating charters and profiles with tertiary providers including ITOs;

- $\quad$ allocating funds to tertiary education providers and ITOs:

- building system capability; and,

- monitoring and evaluation, policy and research.

ITOs are represented by the Industry Training Federation (ITF) which provides a forum for members, collects and produces information on behalf of its members, undertakes research for policy development, makes submissions to government, supports and promotes the image and role of ITOs and encourages cross sector dialogue with parties interested in PCET (ITF, 2002). The ITF works with Skillnz; launched in July 2003 to facilitate cooperative initiatives among the Council of Trade Unions, Business New Zealand and the Government to fund and develop workplace learning and training projects

The current Labour government's goal is to have 250,000 participants in Industry Training and all 15-19 year olds engaged in employment, education or training by 2005 . The 2004 budget added \$25million to the Industry Training Fund with a further $\$ 3$ million for Modern Apprenticeships. In September that year, with increasing skill shortages, a further $\$ 5$ million was provided for industry training with $\$ 8.9$ million over the next four years to fund an additional 1,000 more Modern Apprenticeship places (Maharey, 2004).

The New Zealand strategy has robust quality control procedures. Quality Assurance occurs through the use of industry standards in training and assessment. Standards are regularly reviewed in consultation with industry participants. ITO involvement and workplace assessment facilitate evaluation of the quality of training provision.
They are moderated internally and externally. All Tertiary Providers are audited and must meet NZQA registration standards.

\section{The Development of the Australian Training Strategy}

The delivery of VET in Australia is complicated by the involvement of both the federal and state governments. Until 1966, technical education was a state responsibility (Throughout this paper the term 'state' will be taken to refer to both state and federal territories unless otherwise specified). It was under-funded and under-resourced until the release of the Whitlam Labour Government's Kangan Report in 1972. The report recognised the increasing importance of quality vocational training to the county's future development and recommended the establishment of colleges of Technical and Further Education (TAFE) (Goozee, 2001).

The Hawke Labour Government's 1984 Committee of Inquiry into Labour Market Programs (Kirby Report) introduced the concept of traineeships in response to increasing youth unemployment. The Australian Traineeship System (ATS) departed from previous shortterm labour market programmes as it: introduced yearlong contracts, accredited broad-based off-the-job training; the development through TAFE of state curriculum training packages; coordinated industry and union involvement, and national certification for admission to further education (H. Smith, 1988). The early forecast of 75,000 annual trainees was not met. The total by June 1989 was just over 18,000 (Dumbrell, 2003). Barriers to increased training included existing industrial regulations, employer support for training and Commonwealth/State relationships.

In the late 1980 the development of government policy to provide skills training in the workplace, and the recruitment of union cooperation to achieve greater workplace efficiency and flexibility, were linked in the reform of regulations governing industrial awards (Carmichael, 1989; Dawkins, 1988, 1989). These changes marked the disintegration of national agreements and the growth of enterprise, site and individual agreements. This led to the erosion of union resistance to new apprentices in 'protected occupations' and their employment on individual contracts in new industry areas In 1996 the Workplace Relations Act (1996) introduced Australian Workplace Agreements (AWAs), which enabled employers to enter into individual non-union contracts with employees. Individualised non-registered common law agreements outside of the formal industrial relations framework are also common (Katz, Lee, \& Lee, 2004).

Employer reluctance to train was also regarded as a significant impediment. The Dawkins report (1988) expressed concern at the failure of employers to spend enough on employee training and development. To address this concern the Training Guarantee Scheme was introduced in 1990; employers with payroll costs in excess of $\$ 200,000$ were required to spend up to 1.5 per cent of their payroll on structured employee training for 
their employees. The scheme was withdrawn in 1994 following employer protest (A. Smith, 2003a).

Successive Federal Labour Governments, under the umbrella of the National Training Reform Agenda (NTRA), developed policies to address industry training reform and youth unemployment. The Commonwealth attempted to take control of VET from the states by offering to fully fund post-secondary education and training. The states refused, but in a compromise agreed to work towards, and jointly fund, a national VET system through the Australian National Training Authority, established in 1992. Relationships between state and Commonwealth VET agencies were often confrontational. In addition policy development and implementation by the Commonwealth was often pursued with minimal consultation (G. Hawke \& Cornford, 1998).

In 1996 the Howard Coalition government established the New Apprenticeship programme. The industry led Australian Vocational Training System (AVTS), took effect from January 1998. In many ways the scheme was similar to the 1986 Australian Traineeship Scheme: it promoted the entry-level recruitment of unemployed youth on employment/training contracts for a set duration of one or more years across all industry areas; involved competency-based workplace training and assessment; national certification; a training wage; and 'user-choice' of training provider (Saunders, 2001). Key differences include the extent of funding available to promote the scheme and the structural framework required for its implementation.

The National Qualifications Framework (NQF) was established to register all post-compulsory education qualifications as national qualifications with common institutional criteria. The National Training Framework set guidelines for state regulation of the New Apprenticeship System. The Australia Quality Training Framework (AQTF) was established to ensure the quality of VET services by determining nationally agreed standards for registering training organisations and course accrediting bodies.

Industry Training Advisory Bodies (ITABs) were established to develop training packages and industry training strategies at Commonwealth and State levels. The first training packages were introduced in 1999. Packages contain training support materials, competency standards, assessment guidelines and qualification titles and requirements. In 2002 the Commonwealth announced an end to State ITAB support such that where ITABs still exist, they are under-resourced and dependent upon state and industry assistance. In order to rationalise bureaucracy the twenty-nine National ITABs have been reduced to 10 Skills Councils (Karmel, 2004), a move that required some federal coercion.

The Commonwealth set up New Apprenticeship Centres (NACs) to promote and service New Apprenticeships and administer the Commonwealth's employer incentives program (Goozee, 1999). State government training authorities (STAs) fund and administer training through a variety of providers that are required to register and conform to the standards established by the AQTF. The Registered Training Organisations (RTOs) provide training; assess trainees using competency standards, report achievements and award qualifications. RTOs include TAFE institutes, private training and assessment organisations, enterprises, schools, community organisations and adult education providers. Group Training Organisations (GTOs) had been around since the early 1970s. As RTOs they manage the training and employment of a majority of apprentices and trainees in the traditional trades; many are placed with 'host employers' who provide day-to-day on-the-job training.

Employers are able to employ New Apprentices through a variety of pathways including: their own recruitment processes; New Apprenticeship Centres (NACs); the Job Network; the Jobs Pathway Programme, and Group Training Providers. Trainees are required to sign an employment contract and a training agreement that sets out their roles and responsibilities and includes a training plan and outcomes to be assessed. They may be paid a 'training wage' reflecting time-spent training and may be employed under state awards or enterprise based awards. Australian Workplace Agreements or Certified Agreements allow the employer to vary the mix of training and working time (providing certain conditions are met)

The training system is based upon employer demand and is driven by financial incentives. Commonwealth subsidies and incentives are provided to encourage employers to offer training opportunities (jobs). Incentives of up to $\$ 4,400$ are available subject to new apprentices and employers meeting eligibility criteria. In the 2003-04 financial year the Commonwealth government paid over half a billion dollars in employer incentives. The projected cost to the Commonwealth for 2005 , including the administration of NACs, is about three quarters of a billion (Commonwealth of Australia, 2004). This does not include training and administration costs incurred by state governments. Employer incentive payments were extended to include current employees in 1999; they now make up approximately $30 \%$ of all trainees. Concern has been expressed that some employers were abusing the system by signing up large numbers of employees and providing low quality on-thejob training (of the latter, 2003).

Recognition of Prior Learning (RPL) was to play an important part in the training process by making qualıfications easier to attain by recognising existing skills and competencies. But RPL is not popular in the current VET system. There are no incentives to progress its application and employers prefer the ease and incentives attached to training (Schofield, 2001). State agencies are reluctant to fund RPL due to a distrust of RTO assessment processes and perceived costs (L. Smith, 2004).

The User Choice policy was intended to enable employers and employees to decide who would provide the training. It was also intended to make off-the-job training more responsive to the needs of industry, encourage a competitive providers market to contest the 
privileged position of TAFE, and reduce the cost of training provision (Goozee, op.cit: 97). Ingersoll describes User Choice as a strategy to shift the provision of VET from the supply to the demand side (Ingersoll, 2004).

\section{Outcomes}

Overall, the New Apprenticeship system has produced some major achievements. Large numbers of new employees have been taken directly onto training programmes and large numbers of existing employees have had the opportunity to validate and develop their skills (A. Smith, 2003b).

Brooks (2004:18)) reports "About 15\% of all 15-19-yearold employed persons, were employed as an apprentice or trainee at 31 December 2002". For teenagers not in fulltime education, more than $36 \%$ of those in full-time employment were apprentices or trainees (a relatively constant proportion since 1997). She notes that these figures show "the importance of apprenticeships and traineeships for teenage employment".

Despite the positivity from some quarters many accounts exist of problems with the system. Senate Committee inquiries in 2001 and 2003; a series of reports on training in Australian states, and numerous other research reports raise serious concerns (Buchanan, Considine, \& Hall, 2002; Buchanan \& Eversson, 2004; Buchanan, Evesson, \& Briggs, 2002; Senate Standing Committee on Employment, 2000, 2003) (Dumbrell Consulting Pty Ltd, 2004; Noonan, Burke, \& White, 2004; Schofield, 1999, 2000, 2001a, 2001b).

\section{These concerns include that:}

- some of the New Apprenticeships growth is driven by some employers using the system as a wage subsidy scheme and paying insufficient attention to training (personal communications; Senate Standing Committee, 2003: 212; (Buchanan \& Eversson, 2004); Schoficld, 2001a).

- some trainees feel they are being used as cheap labour and this is a significant factor in noncompletion of traineeships (Cully \& Curtain, 2001, Schoficld, 2001a). In 1998-2003 the national noncompletion rate was optimistically put around $35 \%$. In other words of 1.52 million trainees 530,000 did not complete their traineeships.

- training delivered and monitoring to ensure compliance with Training Agreements is inadequate (Buchanan, Considine et al., 2002; Schofield, 2001b). The 2000 Senate Standing Committee report recommended that ANTA should work to ensure that training plans were properly used and effectively monitored. However ANTA's response was that existing arrangements were adequate (Senate Standing Committee, 2003).
- on-the-job training advantaged employers, especially large employers, as it is usually cheaper. Two large retailers built their in-house training on the back of employer incentives received from signing up trainees. They were able to cover the cost of training existing employees by including them in in-house training with new apprentices (Personal communication).

- employers carrying out fully on the job training resulted in enterprise specific training and thus limited opportunities for trainees to acquire broader knowledge and skills (Senate Standing Committee, 2003).

- "in a system where everyone has a commercial interest, there is no 'honest broker' who can give disinterested advice" (Senate Standing Committee, 2003:212). It is possible for an enterprise, as an NAC, GTO or RTO to approve its own training arrangements, assess its own quality and issue qualifications whilst administering all financial benefits to itself. There is pressure to sign off assessment processes in order to attain the completion payment.

- some NACs and GTOs place trainees without regard to the suitability of the placements. They promote traineeships that are easy to sell and, because these are primarily low-skill jobs in larger enterprises where there are no skill shortages, they are of little benefit to industry (Senate Standing Committee, 2003).

- there has consequently been large growth in relatively low level (Level III) traineeships. This has resulted in a lack of employees with higher skill levels such as in middle and upper management (Buchanan, Evesson et al., 2002; Buchanan, Watson, Campbell, \& Briggs, 2003).

- there has been a decline in traditional apprenticeships resulting in skill shortages in many trades (Buchanan, Considine et al., 2002).

- there are growing numbers of part-time traineeships. In 2002, excluding traditional apprenticeships, 34\% of traineeships were part time. The above points raise the question of whether a creditable training culture exists to equip employees for future employment.

The following table indicates that in New Zealand a higher percentage of trainees are undertaking qualifications at level IV and above. There is no completion incentive in the New Zealand system. By comparison Australian statistics show a trainee preference for level III qualifications. An optimistic view of this Australian trend is employers and trainees realise higher standards of training are of greater value to both parties. A cynical view, expressed by Schofield (2001a), is that the attraction of level III qualifications and above is the completion incentive of $\$ 2,750$; there is no completion incentive for level II qualifications. 
Table 2: Comparison of Trainees by Qualification Level

\begin{tabular}{|l|c|c|c|c|c|}
\hline & Australia 2002 & Australia 2004 & NSW 2003 & NZ 2003 & NZ 2003 \\
\hline Qualification & In train\% (1) & Commence (2) & Commence (3) & In train (4) & Completions \\
\hline Level 1 & 0.0 & 0.0 & 0.0 & 4.0 & 2.7 \\
\hline Level 2 & 18.0 & 14.5 & 35.3 & 22.0 & 22.7 \\
\hline Level 3 & 74.3 & 75.5 & 52.8 & 33.0 & 29.1 \\
\hline Level 4 & 7.5 & 9.7 & 11.9 & 39.0 & 44.0 \\
\hline Level 5+ve & 0.2 & 0.2 & 0.1 & 1.0 & 1.3 \\
\hline Level 6 & 0.0 & 0.0 & 0.0 & 1.0 & \\
\hline
\end{tabular}

Sources: Brooks, 2004; Morgan, 2004; NCVER, 2004a; TEC, 2004

A second table of New South Wales Traineeship statistics illustrates the potential for excessive enterprise access to training and raises questions about government and employer responsibility for training (Morgan, 2004) (The author notes that the apparent anomalies between size of trading enterprise and size of the legal enterprise arises because the trading enterprise is a NSW state entity and the legal enterprise may be a national entity Morgan, 2004). A number of enterprises (I to $\mathrm{N}$ excluding J) have traineeship numbers in excess of employee numbers - in one case almost eight times higher. These figures suggest a) high staff turnover b) all employees being placed on traineeships, and c) accumulation of employer incentive.

Table 3: Number of Traineeships with Individual Enterprises - Jan. 1997 to March 2004 Top 20 Employers by Number of Traineeships (Morgan, 2004)

\begin{tabular}{|l|l|c|c|c|}
\hline & Type of Employer & $\begin{array}{c}\text { Number of } \\
\text { Traineeships }\end{array}$ & $\begin{array}{c}\text { Trading } \\
\text { Business }\end{array}$ & $\begin{array}{c}\text { Legal } \\
\text { Enterprise }\end{array}$ \\
\hline A & Private Retail Enterprise & 2169 & 100,000 & 141840 \\
\hline B & Private Security Enterprise & 2117 & 2,600 & 7844 \\
\hline C & Public Transport Enterprise & 2069 & 8500 & 47893 \\
\hline D & Private Retail Enterprise & 1764 & 65 & 16306 \\
\hline E & Private Telecom Enterprise & 1754 & 2500 & 2500 \\
\hline F & Private Financial Enterprise & 1714 & 7245 & 7245 \\
\hline G & Private Cleaning Enterprise & 1511 & 1000 & 14350 \\
\hline H & Public Educational Enterprise & 1421 & 30 & 333470 \\
\hline I & Private Retail Enterprise & 1219 & 180 & 200 \\
\hline J & Public Transport Enterprise & 1180 & 20 & 6325 \\
\hline K & Private Meat Processing Enterprise & 1175 & 300 & 800 \\
\hline L & Private Retail Enterprise & 1150 & 150 & 150 \\
\hline M & Private Meat Processing Enterprise & 1143 & 650 & 650 \\
\hline N & Private Security Enterprise & 1143 & 850 & 850 \\
\hline O & Retail Enterprise & 1045 & 15000 & 63623 \\
\hline P & Group Scheme & 1742 & N/A & N/A \\
\hline Q & Group Scheme & 1708 & N/A & N/A \\
\hline R & Group Scheme & 1330 & N/A & N/A \\
\hline S & Group Scheme & 1140 & N/A & N/A \\
\hline T & Group Scheme & 1079 & N/A & N/A \\
\hline
\end{tabular}

\section{Comparison}

I have described the Australian strategy as an "over funding" or "free lunch" model in recognition of the availability of funding to employers, and the New Zealand model as a "lite-lunch" model, in recognition of its low level of funding.
The "Free-lunch" Model

The Australian New Apprenticeship systems' main functions are:

- to provide employee training, particularly to youth, and 
- to train as wide a range of workers as possible.

It is driven by:

- Commonwealth government policy;

- Commonwealth incentives to employers to encourage them to engage trainees; and,

- employer demand for training, partially perhaps to reap financial benefits.

- Its positive features may include:

- the reduction of youth unemployment;

- the extension of training into all industry areas and to all employees;

- the facilitation of business based training structures (e.g. enterprise RTOs); and,

- the stimulation of the economy by the expenditure of public funds in the private sector.

Its negative features include:

- a failure to deliver appropriate short term and longterm industry skills;

- funding directed to unnecessary training;

- the use of trainees as low cost labour, resulting in masked productivity increases;

- corruption;

- conflict between Commonwealth and State governments:

- future skill needs are subject to distorted 'market' forces: and.

- a failure to address small businesses needs;

The "Lite-lunch" Model

The New Zealand system's main functions include:

- extending industry training throughout industries and to all employees, and

- encouraging an environment in which ITOs, training providers, employers and trainees cooperate to deliver appropriate training.

It is driven by:

- Government policy and funding to ITOs to manage training:

- ITOs that promote and market training to employers; and.

- employer demand for training.

- Its positive features include:

- a relatively simple administrative structure and a supportive government;

- ITOs that operate at the interface of industry and training :

- people working at grass roots level to achieve the objectives of the industry training system;
- a comprehensive qualifications system that is interlinked with school and VET qualifications so that all student records are coordinated around a National Student Number.;

- funding levels that do not encourage corruption; and,

Its negative features include:

- insufficient funding to meet the demand for training;

- insufficient funding to allow ITOs to fulfil their potential;

- training funding and ITO administrative funding being a lump sum rather than separate funds. ITOs and training providers might adopt practices that generate income for their survival and detract from training needs;

- the lack of an adequate co-ordinating body. The absorption of Skill New Zealand (ETSA) into TEC has resulted in insufficient attention being paid to research, data collection and policy development; and,

- a lack of research and evaluation

\section{Conclusion}

The above analysis does little justice to the undeniable successes of both systems. However it does indicate avenues for further research, including an evaluation of whether the models I have proposed are accurate. A way to deepen understanding of the two countries' industry training systems would be to develop a series of models to describe and explain the different methods of engagement that enterprises adopt when dealing with industry training. Some research has been carried out in Australia, for example: in the operation of Group Training Organisations and in skills formation in Victorian manufacturing industries (Buchanan et. al: 2002, 2004), and the engagement of retail enterprises with the New Apprenticeship scheme (Ingersoll, 2004). There has been some research into ITOs in New Zealand but not in this area (Murray, 2001, 2003, 2003; Piercy, 2003).

It is tempting to suggest that the shortfalls of the Australian New Apprenticeship system are partly a result of the seemingly unlimited amount of Commonwealth funding of employer incentives. Whereas the New Zealand industry training strategy is successful despite limited government funding. New Zealand also has the benefit of simple administrative structures, a supportive national government and ITOs that operate at ground level. A concern for the Australian system is that it may not be sustainable without large amounts of government funding. Further research into the operation of New Zealand's industry training strategy could provide insight for reform of industry training in Australia.

The New Zealand Electrotechnology ITO (ETITO) Executive Director Marilyn Brady in an address to the 2002 ITF conference stated: 
[F]or those companies who sign up their employees to training, there are not the incentives available elsewhere on the globe. There is a subsidy to assist with the cost of training. There is no longer a wage subsidy or skill start payment. There are no tax breaks. New Zealand enterprises are using industry training because of the intrinsic benefits the system offers them in building their skills for their futures (Brady, 2002).

A key question remains: What are the structural, funding and policy arrangements that provide the optimal conditions to sustain an industry training strategy that will enhance the capability of individuals and enterprises?

\section{Notes}

1. Industry training discussed in this paper is workplace-focused training, which may not contain an off-the-job component. It is assessed in terms of a person's competency to reproduce their training in the workplace such that on-the-job assessment is a significant feature.

\section{References}

Barrowman, R. (1996). Qualified Success: A History of the New Zealand Qualifications Authority. Unpublished manuscript, Historical Branch, Department of Internal Affairs, Wellington

Brady, M. (2002). Building Skills for the Future: Opening Address. Wellington: Industry Training Federation. Retrieved 1st May 2004, from http://www.itf.org.nz/conference.htm

Brooks, L. (2004). Australian Vocational Education and Training Statistics: Trends in 'Traditional Apprenticeships'. Adelaide: National Centre For Vocational Education Research. Retrieved 10th January 2005, from http://www.ncver.edu.au /statistic/publications/1453.html

Buchanan, J., Considine, G., \& Hall, R. (2002). You Value What You Pay For: enhancing employers contributions to skill formation and use: a discussion paper for the Dusseldorp Skills Forum. Sydney: Dusseldorp Skills Forum. Retrieved 6th January 2005, from http://www.acirrt.com/ research/resource.htm\#dusseldorp

Buchanan, J., \& Eversson, J. (2004). Creating Markets or Decent Jobs? Group Training and the Future of Work. Adelaide: National Centre for Vocational Education Research. Retrieved 20th October 2004, from http://www.ncver.edu.au/research/proj /nr 1016.pdf

Buchanan, J., Evesson, J., \& Briggs, C. (2002). Renewing the Capacity for Skills Formation: The Challenge for Victorian Manufacturing. Melbourne: Victorian Learning and Employment
Skills Commission. Retrieved 6th January 2005, from http://www.vlesc.vic.gov.au/vlesc/pdfs/ VLESC_ACIRRTreport.pdf

Buchanan, J., Watson, I., Campbell, I., \& Briggs, C. (2003). Fragmented Futures: New Challenges in Working Life. Sydney: The Federation Press.

Carmichael, L. (1989). Award Restructuring Implications For Skill Formation And Training: Australian Council for Trade Unions. Retrieved 1st October 2004, from http://www.actu.asn.au/ public/news/1065074487_19659.html

Chatterjee, S. (Ed.). (1999). The New Politics: A Third Way for New Zealand. Palmerston North: Dunmore Press.

Commonwealth of Australia. (2004). DEST 2004-2005 Budget: Individuals Achieve Relevant Skills and Learning Outcomes From Post-Senate Standing Committeehool Education and Training (Output 2.2). Canberra: AGP. Retrieved 17th November 2004, from http://www.dest.gov.au/budget /PBS /2004/rtf.htm

Connell, J. (2004). Industry and Government Contributions to Industry Training 1996-2000. (pp. Tertiary Education Commission - personal communication). Wellington

Cully, M., \& Curtain, R. (2001). Reasons For New Apprentices' Non-Completions. Adelaide: NCVER. Retrieved 10th November 2004, from http://www.ncver.edu.au/publications/685.html

Dawkins, J. (1988). Industry Training in Australia: The Need for Change. Canberra: AGPS. Retrieved 1st October 2004, from http://www.detya.gov.au/ nbeet/publications/pdf/89_18.pdf

Dawkins, J. (1989). Improving Australia's Training System. Canberra: AGPS

Dumbrell Consulting Pty Ltd. (2004). Literature Review for Review of Traineeships in NSW. Sydney: Dumbrell Consulting Pty Ltd. Retrieved Ist November 2004, from http://www.bvet.nsw. gov.au/pdf/literaturereview.pdf

Dumbrell, T. (2003). Pathways to apprenticeships. Adelaide: NCVER. Retrieved 2nd November 2004, from http://www.ncver.edu.au/research/proj/ nr1015.pdf

ETSA. (1991). The Government's New Industry Skills Training Strategy. Wellington: Education and Training Support Agency 
ETSA. (1994). Report of the Education and Training Support Agency for the year ended 30 June. Wellington: Published by Order of the House of Representatives

ETSA. (1995). Report of the Education and Training Support Agency for the year ended 30 June 1995. Wellington: Published by Order of the House of Representatives, 1991-2000.

ETSA. (1996). Report : of the Education and Training Support Agency for the year ended 30 June. Wellington: Published by Order of the House of Representatives, 1991-2000.

Goozee, G. (2001). The development of TAFE in Australia. Adelaide: National Centre For Vocational Education Research. Retrieved 30th June 2004, from http://www.ncver.edu.au/ vetsystem/publications/574.html

Green, N., Hipkins, C., Williams, P., \& Murdoch, C (2003). A Brief History of Government Funding for Industry Training, 1989-2002. Wellington New Zealand: The Industry Training Federation of New Zealand. Retrieved 30th May 2004, from http://www.itf.org.nz/publications.htm\#Relationsh ips $\% 20$ for $\% 20$ success

Hall, M. (1995). Industry Training: Industry Driven or Manipulative Bureaucracy? Joiners: Official Publication of the NZ Joinery Manufacturers Federation Inc. Retrieved 1st June 2004, from http:/www.tradesecrets.co.nz/Researchpublication $\mathrm{s} / \mathrm{mhallpublications/mhallpulications.htm}$

Hawke, G., \& Cornford, I. (1998). Australian Vocational Education Policy Change: But Will the Revolution Improve the Quality of Training? Australian and New Zealand Journal of Vocational Education Research, 6(2), 104-133

Hawke, G. R. (1988). Report on Post compulsory Education and Training in New Zealand. Prepared for the Cabinet Social Equity Committee hy G.R. Hawke (Hawke Report). Wellington: Department of Education

Ingersoll, L. (2004). Bridging the Skills Divide? An Analysis of Retail Traineeships. Rockhampton: 12th Annual IERA conference

ITF. (2002). Industry Training Federation Inc. Constitution: Revised at 2002 AGM. Wellington: Industry Training Federation. Retrieved Ist May 2004, from http://www.itf.org.nz/

Katz, H. C., Lee, W., \& Lee, J. (2004). The Nen Structure of Lahour Relations: Tripartism and Decentralization. Ithaca: Cornell University Press
Maharey, S. (2000, 13th July 2000). Press Release: Modern Apprenticeship pilots announced Thursday. Wellington: Ministry of Education. Retrieved 20th October 2004, from http://www.scoop.co.nz/mason/archive/scoop/stori es/21/83/200007131527.eeb9cceb.html

Maharey, S. (2004). Addressing New Zealand's skill needs. Wellington: Ministry of Education. Retrieved 20th October 2004, from http://www.beehive.govt.nz/PrintDocument.cfm? DocumentID $=20148$

Ministry of Education. (2001a). Moving Forward: Skills for the Knowledge Economy. Government. Decisions arising from the Review of Industry Training in New Zealand. Retrieved 30th May 2004, from http://wwwl.tec.govt.nz/about_tec /publications.htm\#pubs_m

Ministry of Education. (2001b). Skills for a Knowledge Economy - Nga mohiotanga mo te kohanga whai matauranga: A Review of Industry Training in New Zealand. Wellington, New Zealand. Retrieved 30th May 2004, from http://www.beehive.govt.nz/

Ministry of Education. (2002). Tertiary Education Strategy 2002/07 released 14 May 2002. Wellington, New Zealand: Ministry of Education. Retrieved 30th May 2004, from http://www.minedu.govt.nz/index.cfm?layout=doc ument $\&$ documentid $=6730 \&$ CFID $=1608299 \&$ CFT OKEN $=47818545$

Ministry of Education. (2003). Profile and Trends: The New Zealand Tertiary Education Sector 2002. Wellington: Ministry of Education. Retrieved 20th June 2004, from http://www.minedu.govt.nz/ index.cfm?layout=index\&indexID=8656\&indexpa rentid $=8654$

Morgan, C. (2004). Statistical Trends in Traineeships in New South Wales: 1997 - 2003. Sydney: Workforce Research. Retrieved 1st November 2004, from http://www.bvet.nsw.gov.au/pdf/ statisticaltrends.pdf

Murray, N. (2001). A history of apprenticeship in New Zealand. Unpublished Masters of Social Science, Lincoln University, Lincoln.

Murray, N. (2003). Girls can do anything? Women and industry training in New Zealand. Auckland University of Technology.

Murray, N. (2003). Modern apprenticeships: What's in a name? Paper presented at the 10th Conference on Labour, Employment and Work in New Zealand, 21 st \& 22nd November, 2002, Wellington. 
NCVER. (2004a). Australian vocational education and training statistics: Apprentice and trainee activity, December quarter 2003 - At a glance. Adelaide: National Centre For Vocational Education Research. Retrieved 20th July 2004, from http://www.ncver.edu.au/statistic/publications/148 $0 . \mathrm{html}$

NCVER. (2004b). Australian Vocational Education and Training Statistics: Apprentices and Trainees 2003 - Annual. Adelaide: National Centre for Vocational Education Research. Retrieved 26th October 2004, from http://www.ncver.edu.au/ statistics/aats/ann03/03annsum.pdf

Noonan, P., Burke, G., \& White, P. (2004). Policy Developments in VET: Analysis for Selected Countries. CEET Working Paper No. 54. April 2004. Melbourne: Monash University Centre for the Economics of Education and Training (CEET). Retrieved 2nd November 2004, from http://www.education.monash.edu.au/centres/ceet/ docs/workingpapers/wp54apr04noonan.pdf

Piercy, G. (2003). A 'third way' in industry training: New zealand's adaptation of selected british policies. In C. H. Jorgensen \& N. Warring (Eds.), Adult education and the labour market vii. Volume a (Vol. A, pp. 35-61). Frederiksberg: Roskilde University Press.

Saunders, S. (2001). Issues and directions from a review of the Australian apprenticeship and traineeship literature. Adelaide: National Centre for Vocational Education Research. Retrieved 8th Nonember 2004, from http://www.ncver.edu.au/ research/proj/nr9012i.pdf

Schofield, K. (1999). Independent Investigation into the Quality of Training in Queensland's Traineeship System: Final Report: 2 July 1999. Brisbane: Queensland Apprenticeship Services. Retrieved 10th November 2004, from http://www.qas.org.au/ pdf/Schofield\%20Report.pdf

Schofield, K. (2000). Delivering Quality: Report of the Independent Review of the Quality of Training in Victoria's Apprenticeship and Traineeship System. Adelaide: NCVER

Schofield, K. (2001a). The good, the bad and the ugly: perspectives from three States on the quality of Australia's apprenticeship and traineeship system. Adelaide: NCVER. Retrieved 10th September 2004, from: http://www.ncver.edu.au/files/tr9 schof.rtf

Schofield, K. (2001b). Quality in Context: Reflections on Factors Impacting on the Quality of Apprenticeship and Traineeship Training. In N. Smart (Ed.), Australian Apprenticeships: Research Readings (pp. 239-260). Adelaide: NCVER.
Senate Standing Committee on Employment, W. R. a. E. (2000). Aspiring to Excellence: Report of the Inquiry into the Quality of Vocational Education and Training in Australia. Canberra: Commonwealth of Australia. Retrieved 9th November 2004, from http://www.aph.gov.au/ Senate/committee/eet_ctte/vet/report/

Senate Standing Committee on Employment, W. R. a. E. (2003). Bridging the Skills Divide. Canberra: Commonwealth of Australia. Retrieved 8th November 2004, from http://www.aph.gov.au/ Senate/committee/eet_ctte/skills/report/report.pdf

Skill New Zealand. (2002). Industry Training 2001. Wellington: Skill New Zealand. Retrieved 30th June 2004, from http://www3.tec.govt.nz/ downloads/a2z_publications/industrytraining2001. html

Skill New Zealand. (2003). Final Report of Skill New Zealand Pükenga Aotearoa for the six months ended 31 December 2002. Wellington: Skill New Zealand. Retrieved 30th May 2004, from http://www.tec.govt.nz/downloads/a2z publication s/skillnewzealandfinalreport.html

Smith, A. (2003a). Issues in Employer-based Training and Development: Submission to the Senate Employment, Workplace Relations and Education References Committee on Current and Future Skills Needs. Canberra. Retrieved 1st October 2004, from http://www.aph.gov.au/Senate/ committee/eet_ctte/completed_inquiries/200204/skills/submissions/sub046.pdf

Smith, A. (2003b). Recent Trends in Australian Training and Development. Asia Pacific Journal of Human Resources, 4l(2), 231-244

Smith, H. (1988). Traineeships: A Case Study in New Curriculum Design Methodology. In C. McBeath (Ed.), Case studies in TAFE curriculum. Perth: West Australian Social Science Education Consortium, Curtin University of Technology.

Smith, L. (2004). Valuing Recognition of Prior Learning: Selected Case Studies of Australian Private Providers of Training. Adelaide: NCVER. Retrieved 2nd November 2004, from

TEAC. (2001). Shaping the System: Second Report of the Tertiary Education Advisory Commission. Wellington, New Zealand. Retrieved 30th June 2004, from http://www.tec.govt.nz/about_tec/ publications.htm

TEC. (2003). Industry Training 2002. Wellington: Tertiary Education Commission. Retrieved 30th June 2004, from http://www3.tec.govt.nz/about tec/publications.htm 
TEC. (2004). Industry Training 2003. Wellington: Tertiary Education Commission
Tertiary Education Reform Bill 2002, New Zealand Government (2002), Retrieved 30th May 2004, from http://www.minedu.govt.nz/index.cfm? layout $=$ document $\&$ documentid $=6554 \&$ data $=1$ 